\title{
Chinese hamster ovary cell viability on hydrogen and oxygen terminated nano- and microcrystalline diamond surfaces
}

\author{
Nick Smisdom ${ }^{1}$, llse Smets ${ }^{2}$, Oliver A. Williams ${ }^{3}$, Michaël Daenen ${ }^{3}$, Sylvia Wenmackers ${ }^{3}$, Ken Haenen $^{4}$, \\ Miloš Nesládek ${ }^{4}$, Jan D'Haen ${ }^{4}$, Patrick Wagner ${ }^{4}$, Jean-Michel Rigo ${ }^{1}$, Marcel Ameloot ${ }^{1}$, and Martin \\ vandeVen $^{1,1}$ \\ ${ }^{1}$ Biomedical Research Institute (BIOMED), Hasselt University / transnationale Universiteit Limburg, Agoralaan Bldg. C, B-3590 \\ Diepenbeek, Belgium \\ ${ }^{2}$ Department PHL-Bio, PHL University College, Universitaire Campus, Agoralaan Bldg. E, B-3590 Diepenbeek, Belgium \\ ${ }^{3}$ Institute for Materials Research (IMO), Hasselt University, Wetenschapspark 1, B-3590 Diepenbeek, Belgium \\ ${ }^{4}$ Institute for Materials Research (IMO) \& Division IMOMEC, Hasselt University, Wetenschapspark 1, B-3590 Diepenbeek, Belgium
}

Received zzz, revised zzz, accepted zzz

Published online zzz (Dates will be provided by the publisher.)

PACS 81.05.Uw, 87.17.Ee, 87.17.Rt ,87.85.jj, 87.85.fk

${ }^{1}$ Corresponding author: e-mail martin.vandeven@uhasselt.be, Phone: +32 112693 42, Fax: +32 11269299

Transfected Chinese hamster ovary cells were cultured on bare uncoated chemical vapor deposited thin nanoand microcrystalline diamond surfaces, hydrophobic hydrogen- and hydrophilic oxygen-terminated. Optical and biochemical analyses show that compared to glass controls, growth and viability were not significantly affected (one-way ANOVA). Based on two-way ANOVA analyses, neither grain size nor surface termination had a significant influence until five days post seeding.
1 Introduction Cell-based biosensors require the growth of cells on semiconductors, such as chemically vapor deposited (CVD) diamond. Because of its excellent biocompatibility, i.e. the inertness of diamond for the human body, and haemocompatibility CVD diamond is a material of choice for in vivo applications. Uses of diamond in biomedicine include diamond-coated bone implants [1] and a diamond-based electronic eye [2]. For biosensor applications, diamond has compelling physical, optical, chemical, and electrical characteristics [3]. Suitably doped CVD diamond can be used for field effect transistors (FET), and since the material is transparent and can be deposited on transparent materials such as quartz, simultaneous optical and electrophysiological characterization of growing cells over time is possible.

Cell growth is influenced by substrate surface properties $[4,5]$. In case of diamond, topological height differences of the films increase from $3-5 \mathrm{~nm}$ grain size for ultranano(UNCD), 50-100 nm typically for nano- (NCD) and larger than $100 \mathrm{~nm}$ for microcrystalline diamond $(\mu \mathrm{CD})$ [6].
There is an associated decrease in the relative amount of grain boundaries at the surface, while the topological height differences and thus the roughness of the diamond film increase. Not only surface graininess will influence cell attachment and growth, also the surface termination and coatings play an important role [7]. Hydrogen terminated (HT) diamond surfaces are hydrophobic whereas oxidized diamond surfaces (oxygen terminated, OT) are hydrophilic [3]. In order to obtain better cell survival, diamond surfaces are often coated with laminin, collagen or poly-D or L-lysine [8,9]. However, a direct bioelectronic interface formed between cells and bare substrates (HT or OT) would constitute an advantage over more elaborate methods. Several studies have appeared of cell growth on bare substrates $[1,10]$.

Chinese hamster ovary $(\mathrm{CHO})$ cells present a robust cellular model. $\mathrm{CHO}$ cells have little or no preference for substrate. Stable transfection of $\mathrm{CHO}$ cells with the embryonic homomeric $\alpha_{2}$-glycine receptor $\left(\alpha_{2}\right.$-GlyR) creates the possibility to modulate ion channel expression 
[11]. The use of this robust cell not only avoids the laborious work associated with primary cultures, it also reduces the variability within the cell population. In addition the ligand-gated nature of the ionotropic $\alpha_{2}$ GlyRs, in contrast to voltage-gated ion channels, allows electronic detection of a biological event, i.e. the binding of glycine to its receptor, via alterations in membrane conductance and membrane potential [12].

In this report both qualitative and quantitative results on cell viability of $\mathrm{CHO}$ cells on bare well-characterized HT and OT nano- and microcrystalline diamond film are compared with glass substrate controls. Results obtained with optical and biochemical methods are discussed. This report describes for the first time, as far as we are aware of, $\mathrm{CHO}$ viability on bare OT and HT nano- and microcrystalline diamond.

\section{Materials and methods} 2.1 Preparation of diamond films Both NCD and $\mu \mathrm{CD}$ were grown via microwave plasma-enhanced CVD on ultra-sonically seeded $\mathrm{Si}$ wafers of $5 \mathrm{~cm}$ diameter as described in $[13,14] . \mu \mathrm{CD}$ was grown for a longer duration as compared with NCD, increasing grain size and surface roughness. Film thickness was somewhat thinner near the wafer perimeter [15]. NCD film had a thickness of $\sim 50-$ $200 \mathrm{~nm}[16] ; \mu \mathrm{CD}$ samples were several hundred $\mathrm{nm}$ to a few $\mu \mathrm{m}$ thick [17]. Wafers were cut into about 17 pieces of about $1 \mathrm{~cm}^{2}$. Half of the HT samples was made oxygen terminated by placing them for half an hour in a mixture of $1 \%(\mathrm{w} / \mathrm{v})$ potassium nitrate in sulfuric acid at $250^{\circ} \mathrm{C}$. Substrates were cleaned with spectrophotometric grade isopropanol (Sigma-Aldrich, Steinheim, Germany). To sterilize all substrates were kept for $2 \mathrm{~h}$ at $180^{\circ} \mathrm{C}$. Sulfuric acid, hydrochloric acid and potassium nitrate were purchased from VWR Prolabo (Leuven, Belgium). Samples were regenerated by boiling them for 2 hours in hydrochloric acid under a fume hood after killing the cells with hydrogen peroxide, trypsination, and rinsing away [18]. Glass substrate controls consisted of coverslips (Menzel Gläser, Braunschweig, Germany).

2.2 Cell culturing and growth $\mathrm{CHO}$ cells stably transfected with the embryonic homomeric $\alpha_{2}$-GlyR (B. Rogister, CNCM, Ulg, Belgium) [11], were cultured and maintained in glycine containing high-sugar Dulbecco's modified Eagle's medium (DMEM) supplemented with $10 \%$ heat-inactivated fetal calf serum (FCS), D-dextrose (13.9 $\mathrm{mM}), \quad Z_{\text {eocin }}{ }^{\mathrm{TM}} \quad\left(5 \mu \mathrm{g} \quad \mathrm{ml}^{-1}\right), \quad$ and $2 \%$ penicillin/streptomycin and incubated in a humidified atmosphere of $5 \% \quad \mathrm{CO}_{2}$ and $95 \%$ air at $37^{\circ} \mathrm{C}$. After trypsination and centrifugation the cell pellet was resuspended in fresh growth medium. Cell density was determined with a Fuchs-Rosenthal counting chamber. Cells were seeded well-dispersed at a density of 7,500 cells $\mathrm{cm}^{-2}$ on a random selection of the uncoated substrates in 24-well plates (Nunc ${ }^{\mathrm{TM}}$, Roskilde, Denmark) and incubated in a randomized manner to equalize all parameters. Tests with $1 \mathrm{~cm}^{2}$ glass substrates showed that the resulting variance was small with no significant difference between the randomized and the non-randomized groups [19]. Cell passage number did not exceed eight. All experiments were performed in the exponential growth phase between five and seven days post-seeding, after transferring the substrates to new 24-well plates. Results were normalized to $1 \mathrm{~cm}^{2}$. High-sugar DMEM, penicillin/streptomycin (10000 U/ml and $10000 \mu \mathrm{g} / \mathrm{ml}$ were from Gibco (Paisley, UK), FCS from Hyclone Europe S.A. (ErembodegemAalst, Belgium), D-dextrose from VEL (Leuven, Belgium) and Zeocin ${ }^{\mathrm{TM}}$ from Invitrogen (Carlsbad, CA, USA).

2.3 Optical characterisation Cell-covered NCD and $\mu C D$ substrates were visually inspected in their plate wells in reflection with an upright microscope (Nikon Optiphot, Nikon, Japan) equipped with dichroic mirror without or with excitation and emission polarizers and a digital camera. Substrate structure, cell morphology and density were observed with a Quanta 200-FEG SEM (FEI Corp., Hillsboro, OR., USA). This also allowed a perspective view to check for $\mathrm{CHO}$ cell aggregates on top of the monolayers even to tilt angles of $70^{\circ}$. Cell fixation at room temperature for $10 \mathrm{~min}$. with $2 \%(\mathrm{v} / \mathrm{v})$ glutaraldehyde in $0.03 \mathrm{M}$ Na-cacodylate $\mathrm{pH} 7.3$ buffer was followed by two wash steps of $5 \mathrm{~min}$. each with this buffer. After postfixation treatment with osmium tetroxide for $10 \mathrm{~min}$. cells were rinsed with distillated water. SEM images of the fixated cells, dehydrated in an alcohol series $(30,50,70$, 90 , and $100 \%)$, were taken in high vacuum $\left(\sim 10^{-5}\right.$ mbar $)$ for cells on diamond substrates, and in low vacuum $(\sim 0.9$ mbar) using water vapor to prevent charging effects for cells on glass substrates. Osmium tetroxide improved contrast for glass substrates, for diamond the opposite effect was observed. Paraformaldehyde, glutaraldehyde, Na-cacodylate and osmium tetroxide were from Sigma (Bornem, Belgium).

2.4 Flow cytometric viability assay Fractions of living, necrotic and apoptotic cells (typically 10,000) were determined using a FACScan (Becton Dickinson, San Jose, CA, USA). Calcein-AM, Propidium Iodide (PI) and Pluronic ${ }^{\circledR}$ F-127 were from Molecular Probes (Eugene, OR, USA). After trypsination with $0.25 \%$ trypsin / $1 \mathrm{mM}$ EDTA during 3 min., inactivation of trypsin with FCS, the cell suspension as well as the substrates' PBS pH 7.2 rinsings were transferred to a 96 -well plate. This plate was centrifuged twice $(10 \mathrm{~min}$. at $1,000 \mathrm{xg}$, centrifuge 5810 , Eppendorf AG, Hamburg, Germany), the supernatant aspirated and the cell pellet resuspended with PBS pH 7.2. The suspension was incubated for $10 \mathrm{~min}$. in the dark at room temperature with flow cytometry loading buffer.

2.5 Biochemical characterization Cell growth and viability were characterized with the $\left[{ }^{3} \mathrm{H}\right]$-thymidine cell 
proliferation assay, the Bradford assay for total protein content, and the 3-(4,5-dimethylthiazol-2-yl)-2,5diphenyltetrazolium bromide (MTT) cell proliferation assay. Normalization to substrate area was carried out and both the MTT and the $\left[{ }^{3} \mathrm{H}\right]$-thymidine assay results were divided by those obtained with the Bradford assay.

$\left[{ }^{3} \mathrm{H}\right]$-thymidine cell proliferation assay. $16 \mathrm{~h}$ prior to the experiment, cells were incubated with $1 \mu \mathrm{Ci}\left[{ }^{3} \mathrm{H}\right]$ thymidine (Amersham Biosciences, Diegem, Belgium). Cell growth medium and trypsin-treated cells were collected and centrifuged for $10 \mathrm{~min}$ at $3,500 \times \mathrm{g}$ (Biofuge 15, Heraeus Sepatech, Osterode, Germany). After resuspension in $\mathrm{PBS} \mathrm{pH}$ 7.2, the cellular material was harvested and radioactivity measured as described [20].

Bradford assay for total protein content. Cell growth medium and trypsin-treated cells were collected and centrifuged for $10 \mathrm{~min}$. at $425 \times \mathrm{g}$ and $37{ }^{\circ} \mathrm{C}$. After resuspension in $750 \mu 10.1 \mathrm{~N} \mathrm{NaOH}$ and $15 \mathrm{~min}$. incubation at $37^{\circ} \mathrm{C}, 20 \mu \mathrm{l}$ of each sample was added to four replicate wells of a flat-bottom 96-well plate. After addition of 270 $\mu \mathrm{l}$ color reagent to each well, the plate was incubated for $10 \mathrm{~min}$. and absorbances measured at $630 \mathrm{~nm}$ with an ELISA plate reader (ICN Biomedicals, Asse, Belgium). A serial dilution of bovine serum albumin was used as calibration curve. The color reagent consisted of $0.1 \mathrm{~g} \mathrm{ml}^{-1}$ Serva Blue G dye, $0.05 \%$ (v/v) ethanol $95 \%$, and $0.1 \%$ $(\mathrm{v} / \mathrm{v})$ phosphoric acid.

MTT cell proliferation assay. Absorbances were recorded on a Shimadzu UV/VIS scanning spectrophotometer UV1600 PC (Shimadzu Benelux, Deurne-Antwerp, Belgium) at 550 and reference $800 \mathrm{~nm}$ with $1 \mathrm{~nm}$ step size, $0.1 \mathrm{~s}$ integration time, $\sim 20-23^{\circ} \mathrm{C}$. MTT assay solvent consisted of DMSO enriched with $15 \%$ 0.1 M TRIS buffer pH 10 to mimic the endpoint of the MTT assay. The assay was optimized as described [19,21]. Dimethylsulfoxide (DMSO, spectroscopic grade), TRIS-(hydroxymethyl)amino-methane and $\mathrm{NaCl}$ were from ACROS Organics (Geel, Belgium), MTT (M 5655), glycine from Sigma (Bornem, Belgium), MTT-formazan from Fluka (Buchs, Switzerland).

2.6 Statistics Graphing and statistical analysis was performed using Prism ${ }^{\circledR} 4$ (GraphPad Software, Inc., San Diego, CA, USA). Data from the biochemical assays were normalized to $1 \mathrm{~cm}^{2}$ surface area and to the respective glass controls values. When applicable, data were analyzed using one-way-analysis of variance (ANOVA) with a Bonferroni post test to compare with glass controls, and with two-way ANOVA to search for significant influences of NCD, $\mu C D$ surface characteristics or hydrogen/oxygen termination. All p-values lower than 0.05 were considered significant. Error bars represent one standard error of the mean.

\section{Results and discussion}

3.1 Surface topology and cell morpohology Typical morphology and topology for clean NCD and $\mu C D$ samples (without cells) are presented (Fig. 1). NCD film (200 $\mathrm{nm}$ thick) root mean square (RMS) surface roughness typically was $10 \mathrm{~nm}$ as reported [3] while for $\mu \mathrm{CD}(3.2 \mu \mathrm{m}$ thick) RMS roughness was $100 \mathrm{~nm}$ [3]. Contact angles and surface wettability were similar to those reported [3], i.e. $>90^{\circ}$ for $\mathrm{HT}$ and $<45^{\circ}$ for OT films. SEM images of cell covered NCD and $\mu \mathrm{CD}$ show a monolayer of nicely spread cells at five days post-seeding (Fig. 2) with spreading and flattened morphology and apparent absence of cytotoxicity [10]. On $\mu \mathrm{CD}$, the cell membrane sometimes followed the crystal delineation. Coverslip glass substrate (Fig. 3) contrast was improved using osmium tetroxide. In contrast with [5], we observed a confluent monolayer. The few aggregates on top of the monolayer seem not to be due to seeding since even very evenly dispersed cells show this effect after reaching full confluence. Surface wettability might modulate cell adhesion at least in part [5]. Similar to SEM, visual inspection indicated no disadvantageous influence of the substrates on the cells. Reflection microscopy with through-the-lens illumination and contrast enhancement through polarizers allowed convenient monitoring of cell layer morphology and density over time with images of comparable quality as published [22].

3.2 Cell doubling time Cells did not detach nor did overgrowth domes form up to day seven. Fig. 4 shows $\mathrm{CHO}$ cells exhibiting exponential growth. Samples were treated as described for the MTT proliferation assay. Cell numbers were obtained from an area and DMSO corrected absorbance standard curve. Fitting days 4-7 post-seeding, $\mathrm{R}^{2}$-correlation coefficient values were 0.99 or better. Doubling times were very similar: $23.7 \pm 1.9$ and $23.3 \pm$ $3.1 \mathrm{~h}$ for OT-NCD and OT- $\mu$ CD. For HT-NCD and HT$\mu \mathrm{CD}$ they were $21.6 \pm 0.2$ and $25.1 \pm 2.5 \mathrm{~h}$ while for glass controls $22.0 \pm 1.5 \mathrm{~h}$. Within fit error no significant differences exist. CHO cells proliferated on bare cleaned surfaces irrespective of the type of diamond and/or surface termination. This is similar to osteoblast-like cells and pneumocytes growing on NCD/amorphous carbon composite films [23]. On the contrary, HK-2 epithelial cells showed a strong difference in attachment between HT and OT terminated NCD [24]. However no difference was observed for $2-5 \mathrm{~nm}$ diamond particles of either termination. Mouse fibroblast L929 permanent cell line and human gingival fibroblast showed a slightly higher proliferation on NCD films as compared with control polystyrene [10]. Surface topologies of our NCD and $\mu C D$ surfaces apparently were sufficiently similar without large and sudden height variations which might have impeded growth as shown for spiky boron doped NCD surfaces $[1,4]$. 

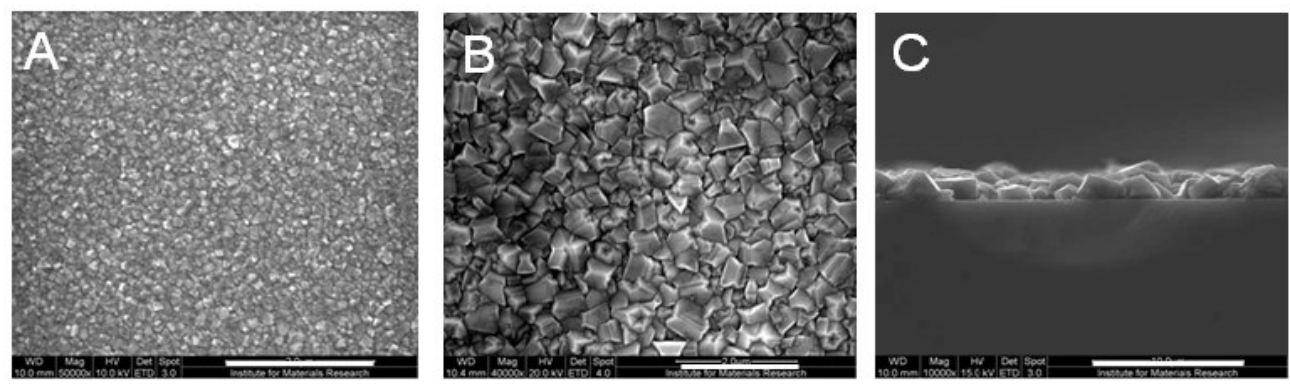

Figure 1 SEM images of nano- $(\mathrm{NCD})$ and microcrystalline $(\mu \mathrm{CD})$ diamond films on silicon. Nano- $(\mathrm{A})$ and microcrystalline (B) diamond film (scale bars $2 \mu \mathrm{m}$ ). (C) cross-section of a microcrystalline diamond substrate. (scale bar $10 \mu \mathrm{m}$ ).
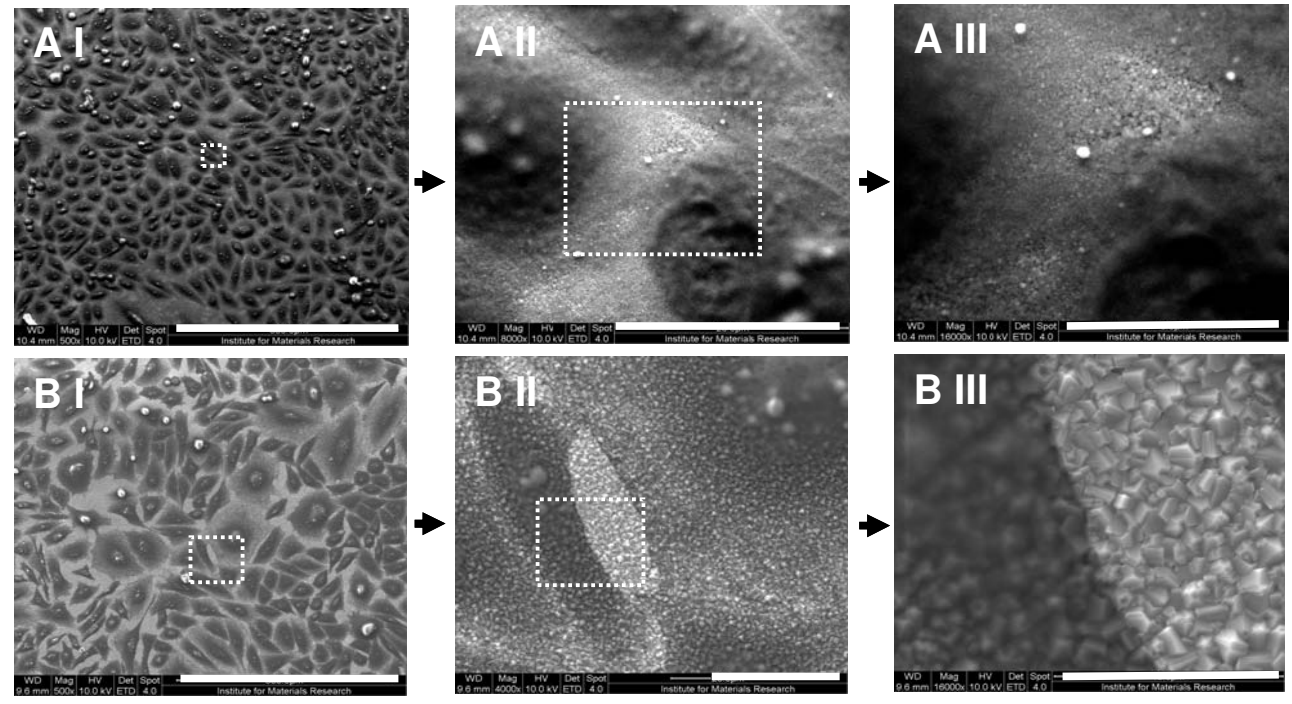

Figure 2 SEM images of CHO cellular monolayers on diamond. After five days post seeding, cells grown on OT-NCD (A) and HT- $\mu$ CD (B) were fixated and dehydrated. Images show a monolayer of cells on top of the diamond surfaces. Scale bars $300 \mu \mathrm{m}$ (A.I, B.I), $20 \mu \mathrm{m}$ (A.II, B.II) and $10 \mu \mathrm{m}$ (A.III, B.III).
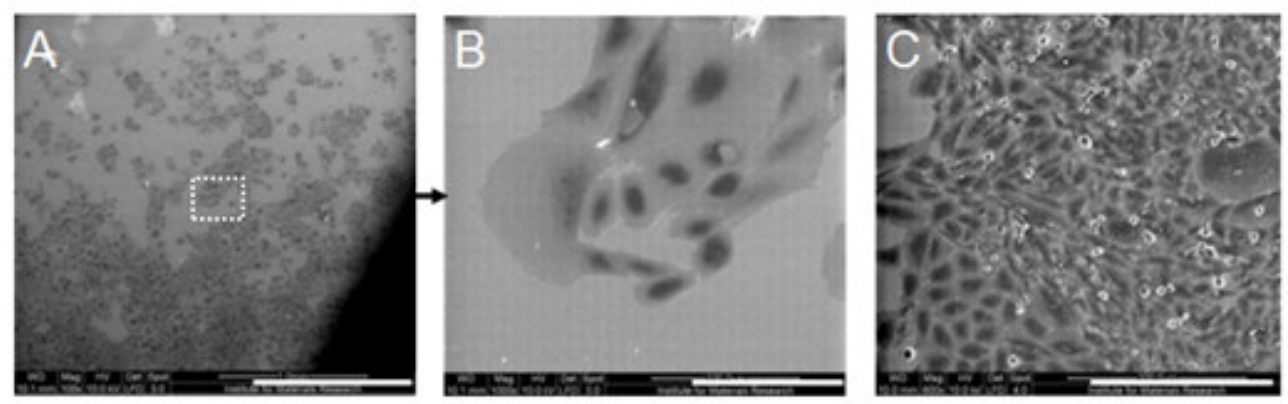

Figure 3 SEM images of $\mathrm{CHO}$ cells on glass substrates. After five days post seeding, fixated and dehydrated cells grown on glass substrate controls (A), (B) (enlarged area). Near the bottom (A) a subconfluent monolayer can be seen. (C) Improved contrast via post-fixation osmium tetroxide application. Same conditions otherwise. Scale bars are respectively $1 \mathrm{~mm}, 100 \mu \mathrm{m}$ and $200 \mu \mathrm{m}$. Dashed square indicates magnified section.

3.3 Flow cytometry Living cells were indicated by the presence of calcein fluorescence and absence of PI fluorescence. Necrotic cells were characterized by their PI fluorescence due to leaking membranes, regardless of calcein fluorescence. In contrast, apoptotic cells were low for both calcein and PI fluorescence. Fig. 5 shows no significant differences between tested substrates, and this for all cell populations involved. This finding corresponds with the reflection microscopy and SEM results. 


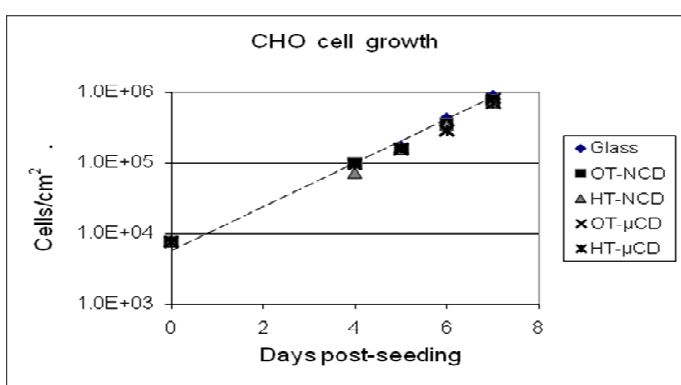

Figure 4 Cell growth on as-grown cleaned HT- and OT diamond and glass control surfaces. Day 4-7 linear fit through cells growing on glass.

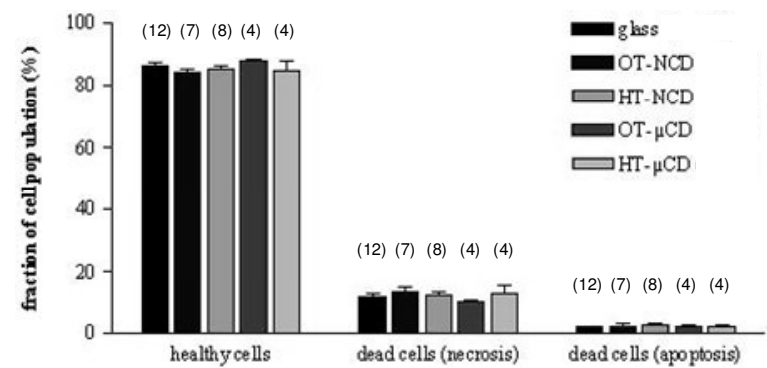

Figure 5 Flow cytometric analysis of healthy, necrotic and apoptotic cells using calcein-AM and PI five days post seeding. No significant difference could be demonstrated between all substrates tested using one-way ANOVA. (n) indicates the number of repeats. Error bars represent one standard error of the mean.

3.4 Cell viability, proliferation and total protein content The $\left[{ }^{3} \mathrm{H}\right]$-thymidine assay showed that neither the uncorrected nor the for total protein content corrected proliferation rate was significantly different using one-way ANOVA. This was consistent with the results obtained with the Bradford assay (not shown). Determining the total protein content is a good estimate of the total cell number. The $\mathrm{R}^{2}$-value of the Bradford assay calibration curve with bovine serum albumin (BSA) was 0.9998 (result not shown). No significant difference could be demonstrated between the glass substrate controls and the diamond substrates using one-way ANOVA. The optimized MTT cell proliferation assay corrected for total protein content, was executed at five and seven days post-seeding (Fig. 6). In general, the differences in cell metabolic activity between glass substrate controls and diamond substrates decreased. After five days, no significant difference could be demonstrated between the substrates using one-way ANOVA analysis. In contrast, after seven days OT and HT-NCD as well as HT- $\mu$ CD diamond were significantly different using one-way ANOVA $(\mathrm{p}<0.01)$. Furthermore, two-way ANOVA did not reveal a significant influence on the type of diamond. On the other hand, surface termination was found to have a significant influence, although only after seven days $(\mathrm{p}<0.01)$. Compared to glass only the HT samples differed significantly indicating the significant negative influence of hydrogen terminated surfaces. Conversely, two-way ANOVA revealed an even more significant effect of surface termination after seven days $(p<0.001)$. This is consistent with [5]. This finding warrants further research over more extended periods of time. The amount of protein per cell may not be the same for each substrate [25]. Furthermore, a growth phasedependent protein expression could occur as seen with bacteria [26].

Unlike most topologies used to study possible effects, diamond surfaces are just 'non-structured and rough'. This roughness is thought to aid cell adhesion [27]. Additional factors may well be involved. For example UV irradiation of substrates mediated by the electrostatic interactions or the hydrogen bond formation between cell membrane proteins and diamond surfaces seems to aid in cell growth $[28,29]$. A nanometer thin serum protein coating [30], due to the required use of FCS, may influence $\mathrm{CHO}$ cell attachment and growth and may give part of the explanation for the observed substrate indifference. Serum protein interaction with HT and OT terminated surfaces may also mediate and lead to preferential cell adhesion [31] and these effects should be studied in more detail. $\mathrm{CHO}$ cells were healthy as patch-clamp results show that the glycine presence in DMEM does not down-regulate the glycine receptor [11] nor cause an increase in cell death.

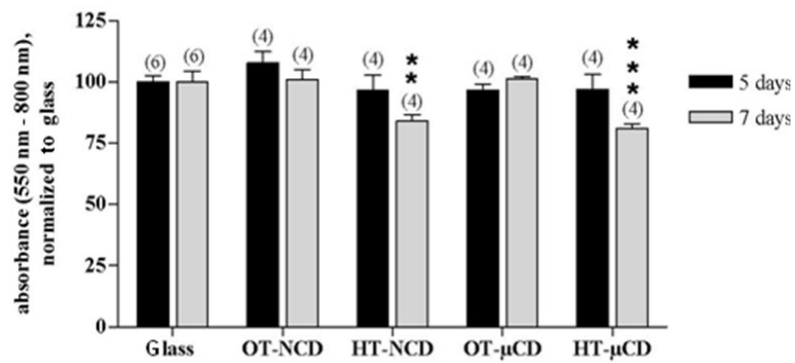

Figure 6 Comparison of $\mathrm{NCD}$ and $\mu \mathrm{CD}$, either OT or HT, with glass substrate controls using the MTT assay results normalized to total protein content obtained with the Bradford assay. Absorbance was normalized to both $1 \mathrm{~cm}^{2}$ and to glass substrate controls. Five days post seeding (black), no significant difference was demonstrated. Conversely, seven days post seeding (gray) a significant difference was present $(\mathrm{p}<0.01)$. Significance levels shown are from comparison with glass substrate controls. $\left(^{* *}=\right.$ $\mathrm{p}<0.01, * * *=\mathrm{p}<0.001)$. (n) above bars indicates the number of repeats. Error bars represent one standard error of the mean.

4 Conclusions Based on the acquired results, it is justified to conclude that for the transfected $\mathrm{CHO}$ cells considered, growth and viability on bare uncoated nanoand microcrystalline diamond substrates is not substantially attenuated with respect to the glass control, at least up to day five. The surface roughness of the diamond surfaces used in this report forms apparently no statistically significant hindrance for the growing and proliferating $\mathrm{CHO}$ cells, cushioned as they are by their own extra cellular matrix. The effects of grain size and 
serum are currently not straightforward to explain and warrant further research.

Acknowledgements The authors thank Mrs. R. Beenaerts, Mr. J. Janssen, Mr. P. Pirotte, Mr. J. Soogen, Mr. R. van Werde for expert laboratory assistance, Prof. Dr. I. Lambrichts and Mr. M. Jans for logistics and fixation procedures, Mr. K. Vanstreels and Mr. B. Ruttens for assistance with the scanning electron microscope, Prof. Dr. R. Valcke for the use of his spectrophotometers, Mr. J. Duchateau, Mr. F. Horemans, Mrs. V. Vrindts for cleaning the diamond substrates, Ir. L. Naelaerts (KHLIM) for lending stereo microscopes. S.W. is a postdoctoral research fellow of the Research Foundation - Flanders (FWOVlaanderen). This work was funded by the Research Council of the UHasselt, tUL, the K.U.Leuven (GOA/2006/02) and by a Ph.D grant of the Institute for the Promotion of Innovation through Science and Technology in Flanders (IWT-Vlaanderen). Support by IAP P6/27 Functional Supramolecular Systems (BELSPO) and by the FWO-onderzoeksgemeenschap "Scanning and Wide Field Microscopy of (Bio)-organic Systems" is gratefully acknowledged.

\section{References}

1 M. Kopecek, L. Bacakova, J. Vack, F. Fendrych, V. Vorlicek, I. Kratochvilova, V. Lisa, et al., PSS (A), 205, 2146 (2008).

2 X. Xiao, J. Wang, C. Liu, J. A. Carlisle, B. Mech, R. Greenberg, D. Guven, et al., J. Biomed. Mater. Res. Part B: Appl. Biomater., 77B, 273 (2005).

3 S. Wenmackers, V. Vermeeren, M. vandeVen, M. Ameloot, N. Bijnens, K. Haenen, L. Michiels, et al., PSS (A), 206, 391 (2009).

4 N. W. Karuri, S. Liliensiek, A. I. Teixeira, G. Abrams, S. Campbell, P. F. Nealey, and C. J. Murphy, J. Cell Science, 117, 3153 (2004).

5 B. S. Zhu, Q. H. Lu, J. Yin, J. Hu, and Z. G. Wang, Biomed. Mater. Res., 70B, 43 (2004).

6 P. W. May, M. N. R. Ashfold, and Y. A. Mankelevich, J. Appl. Phys., 101, 053115-1 (2007)

7 K. F. Chong, K. P. Loh, S. R. K. Vedula, C. T. Liom, H. Sternschulte, D. Steinmueller, F. S. Sheu, et al., Langmuir, 23, 5615 (2007).

8 P. Ariano, P. Baldelli, E. Carbone, A. Gilardino, A. Lo Giudice, D. Lovisolo, C. Manfredotti, et al., Diamond Relat. Mater. 14, 669 (2005).

9 P. Bajaj, D. Akin, A. Gupta, D. Sherman, B. Shi, O. Auciello, and R. Bashir, Biomed Microdev., 9, 787 (2007).

10 M. Amaral, P. Gomes, M. Lopes, J. Santos, R. Silva, and M. Fernandes, Acta Biomaterialia 5, 755 (2009).

11 J. M. Mangin, M. Baloul, L. Prado De Carvalho, B. Rogister, J. M. Rigo, and P. Legendre, J. Physiology $\mathbf{5 5 3}$ 369 (2003).

12 M. Schmidtner and P. Fromherz, Biophys. J. 90, 183 (2006).

13 M. Daenen, O. A. Williams, J. D'Haen, K. Haenen, and M. Nesládek, PSS (A), 203, 3005 (2006).
14 O. A. Williams, M. Nesládek, M. Daenen, M. Michaelson, A. Hoffman, E. Osawa, K. Haenen, et al., Diamond Relat. Mater., 17, 1080 (2008).

15 S. Wenmackers, S. D. Pop, K. Roodenko, V. Vermeeren, O. A. Williams, M. Daenen, O. Douhéret, et al., Langmuir, 24, 7269 (2008).

16 M. Tachiki, T. Fukuda, H. Seo, K. Sugata, T. Banno, H. Umezawa, and H. Kawarada, Mat. Res. Soc. Symp. Proc., 675, W12.5.1 (2000).

17 O. A. Williams, O. Douhéret, M. Daenen, K. Haenen, E. Osawa, and M. Takahashi, Chem. Phys. Lett., 445, 255 (2007).

18 D. D. Nguyen, X. Huang, D. W. Greve, and M. M. Domach, Biotech. Bioeng., 87, 138 (2004).

19 H. Wan, R. Williams, P. Doherty, and D. F. Williams, J. Mater. Sci. Mater. Med., 5, 154 (1994).

20 K. Venken, M. Thewissen, N. Hellings, V. Somers , K. Hensen, J.L. Rummens, and P. Stinissen., J Immunol Methods. 322, 1 (2007).

21 J. A. Plumb, R. Milroy, and S. B. Kaye, Cancer Res., 49, 4435 (1989).

22 E. Bogner, K. Dominizi, P. Hagl, E. Bertagnolli, M. Wirth, F. Gabor, W. Brezna, and W. Wanzenboeck, Acta Biomaterialia, 2, 229 (2006).

23 C. Popov, W. Kulisch, J. P. Reithmaier, T. Dostalova, M. Jelinek, N. Anspach, and C. Hamman, Diamond Relat. Mater., 16, 735 (2007).

24 T. Lechleitner, F. Klauser, T. Seppi, J. Lechner, P. Jennings, P. Perco, B. Mayer, et al., Biomater. 29, 4275 (2008).

25 B. B. Hasinoff, M. E. Abram, G. L. Chee, E. Hueber, E. H. Byard, N. Barnabe, V. J. Ferrans, et al., J. Pharmacol. Exp. Ther., 295, 474 (2000).

26 S. L. Walker, J. E. Hill, J. A. Redman, and M. Elimelech, Appl. Environ. Microbiol., 71, 3093 (2005).

27 A. Curtis and C. Wilkinson, Biomater. 18, 1573 (1997).

28 K. F. Chong, K. P. Loh, S. R. K. Vedula, C. T. Liom, H. Sternschulte, D. Steinmueller, F. S. Sheu, et al., Langmuir, 23, 5615 (2007).

29 G. Speranza, S. Torrengo, L. Minati, M. Filippi, M. Castellino, C. Manfredotti, C. Manfredotti, et al., Diamond Relat. Mater., 17, 1194 (2008).

30 B. Rezek, E. Ukraintsev, L. Michalíková, A. Kromka, J. Zemek, M. Kalbacova, Diamond Relat. Mater. 18, 918 (2009).

31. M. Kalbacova, L. Michalikova, V. Baresova, A. Kromka, B. Rezek, and S. Kmoch, PSS (B), 245, 2124 (2008). 